\title{
HOW STAR WARS ILLUMINATES \\ CONSTITUTIONAL LAW
}

CASS R. SUNSTEIN ${ }^{\dagger}$

\begin{abstract}
Human beings often see coherence and planned design when neither exists. This is so in movies, literature, history, economics, and psychoanalysis - and constitutional law. Contrary to the repeated claims of George Lucas, its principal author, the Star Wars series was hardly planned in advance; it involved a great deal of improvisation and surprise, even to Lucas himself. Serendipity and happenstance, sometimes in the forms of eruptions of new thinking, play a pervasive and overlooked role in the creative imagination, certainly in single authored works, and even more in multi-authored ones extending over time. Serendipity imposes serious demands on the search for coherence in art, literature, history, and law. That search leads many people (including Lucas) to misdescribe the nature of their own creativity and authorship. The misdescription appears to respond to a serious human need for sense-making and pattern-finding, but it is a significant obstacle to understanding and critical reflection. Whether Jedi or Sith, many authors of constitutional law are a lot like the author of Star Wars, disguising the essential nature of their own creative processes.
\end{abstract}

KEYWORDS: Serendipity; Judicial Interpretation; Supreme Court; Chain Novel; Originalism.

RESUMO: Os seres humanos frequentemente identificam coerência e planejamento quando nenhum desses elementos sequer existe. Tal situação ocorre nos filmes, na Literatura, na História, na Economia e na

\footnotetext{
${ }^{\dagger}$ Robert Walmsley University Professor, Harvard University. For valuable comments, I am grateful to Tyler Cowen, Elizabeth Emens, George Loewenstein, Martha Nussbaum, Eric Posner, Mark Tushnet, Adrian Vermeule, and Duncan Watts. This essay draws heavily on an earlier and less academic essay, originally published in The New Rambler (2015).
} 
Psicanálise - e no Direito Constitucional. No âmbito do cinema, a saga de Guerra nas Estrelas não foi idealizada a priori; apesar das repetidas afirmações de George Lucas, principal autor da obra; o que agrega à construção da série os componentes surpresa e improviso - inclusive para o próprio Lucas. Dessa forma, se já é natural que a interpretação assuma um papel pervasivo e orientador da imaginação criativa em forma de manifestação de um novo pensamento, em trabalhos individuais, mais natural ainda é que essa "serendipidade" (serendipity) ${ }^{1}$ ocorra em obra de múltiplos autores e escrita ao longo do tempo. A "serendipity" impõe rigorosas exigências na busca pela coerência na Arte, na Literatura, na História e no Direito. Essa busca leva muitas pessoas (como o próprio Lucas) a descrever de forma imprecisa a natureza de seu processo criativo. A imprecisão surge em resposta à séria necessidade humana de conferir sentido e identificar padrões, o que é um obstáculo significativo para a compreensão e reflexão crítica. Independentemente de serem Jedi ou Sith, muitos Constitucionalistas muito se parecem com o autor de Guerra nas Estrelas, quanto à simulação da essência do seu processo criativo.

PAlAVRAS-ChaVE: Serendipidade; Interpretação Judicial; Suprema Corte dos EUA; Romance em Cadeia; Originalismo.

${ }^{1}$ [N.T.] Serendipity, por uma livre tradução, seria uma feliz coincidência, um acontecimento positivo provocado pelo acaso. 
Review of Chris Taylor, How Star Wars Conquered the Universe (2014) ${ }^{2}$

Lawrence Kasdan: I'm saying that the movie has more emotional weight if someone you love is lost along the way; the journey has more impact.

George Lucas: I don't like that and I don't believe that. ${ }^{3}$

\section{TABLE OF CONTENT:}

I. THERE IS NO JOURNAL OF THE WHILLS.......................................565

II. "I AM YOUR FATHER" ..........................................................................567

1. Origins ...............................................................................................567

2. Serendipity and Coherence .......................................................569

III. THE "I AM YOUR FATHER" CONSTITUTION ...................................572

1. An Arresting Metaphor .............................................................572

2. "I Don't Like That and I Don't Believe That" ......................573

IV. SERENDIPITY AND THE JOURNAL OF THE WHILLS ..........................575

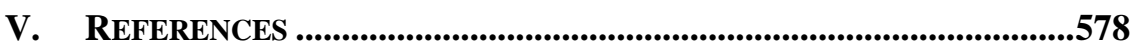

\section{SUMÁRIO:}

I. NÃO HÁ JOURNAL OF THE WHILLS.......................................................565

II. "Eu SOU SEU PAI" ...............................................................................567

1. Origens.....................................................................................567

2. Serendipidade e Coerência........................................................569

III. A Constituição "Eu Sou Seu PaI" ..................................................572

1. Uma Metáfora Brilhante ......................................................567

2. “Eu Não Gosto Dessa Ideia e Não Acredito Nela"...............569

IV. SERENDIPIDADE E JOURNAL OF THE WHILLS....................................575

V. REFERÊNCIAS.........................................................................................578

2 Chris TAylor, HOW StAR WARs CONQUERED THE UniVERSE: THE PAST, PRESENT, AND FUTURE OF A MULTIBILLION FRANCHISE (2014).

${ }^{3}$ Quoted in J.W. RINZLER, THE MAKING OF STAR WARS: RETURN OF THE JEDI: THE DEFINITIVE STORY, 64 (2013). 


\section{THERE IS NO JOURNAL OF THE WHILlS}

Do narratives cohere? In literature? In history? In law? In individual lives? Human beings think so. They like patterns, and they like to think that if they know enough, the various pieces will fit together. They might be right. But everything depends on the nature of the pieces, and what it means for them to fit.

Often people think that for important works, there is some kind of designer, who figured it all out in advance, and whose essential plan is responsible for everything that follows. Perhaps the designer is a person: William Shakespeare, Leonardo da Vinci, George Washington, John Marshall, Franklin Delano Roosevelt, Ronald Reagan, Barack Obama. Perhaps the designer is personified: the founders, Congress, We the People. But designers themselves are often improvisers, and they may have nothing that counts as a plan.

If we claim that what they produce is coherent, it may well be because of our work, not theirs. Acts of interpretation often involve the creation of coherence where it did not exist before. Sometimes the inspiration is a general account or an overarching abstraction, producing some kind of grand narrative. The Equal Protection Clause reflects an anticaste principle; Hamlet is about an Oedipal conflict; Charles Dickens was interested in class struggle; Reagan's presidency was a restoration of limited government. Sometimes people attempt to produce coherence through the assembly of telling details, some of them seemingly irrelevant. The placement of a comma, the use of the word "the" rather than " $a$," the addition of an " $s$ " at the end of a word - all these can suggest a plan where we might otherwise be at sea.

Conspiracy theorists are masters of this approach. Even more than the rest of us, they suffer from what we might call serendipity neglect: a disregard of the extent to which random or arbitrary factors are responsible for social outcomes. Conspiracy theories comb through vast materials, findings countless patterns and links, and then declaring their suspicions to be confirmed. Psychoanalysts are certainly subject to serendipity neglect: They purport to find patterns in dreams, thoughts, and behaviors, even when those patterns are constructed post hoc rather than found. (To their credit, they do know that sometimes a pipe is just a pipe.)

We can easily find serendipity neglect in literary criticism and in the pseudosciences, such as astrology; many economists fall victim to the same problem. The Bible Code is a terrific example. ${ }^{4}$ There is a close

${ }^{4}$ Michael Drosnin, The Bible Code (1998).

2 JOURNAL OF INSTITUTIONAL STUDIES 2 (2016) 
analogy in the domain of visual perception: Our brains are wired to see patterns where they do not in fact exist ("patternicity"5). Serendipity neglect does not involve sensory perception, but human beings (emphatically including lawyers and judges) are sense-making animals. One way to make sense is to neglect serendipity.

Here is an account of the six movies that now constitute Star Wars:

George Lucas wrote Episode IV: A New Hope, the first of the six movies in the series, with a clear understanding of the plots and sequences of all six. He knew that the central characters would be a father and twins. He knew that Darth Vader ("Dark Father") was Annakin Skywalker, Luke Skywalker's father. He knew that Luke and Leia were twins. He knew that Obi-Wan Kenobi was responsible for the horrific injuries that ultimately put Darth Vader in a kind of mechanical armor. He knew that ultimately, Luke Skywalker, Vader's son, would redeem his father by turning him from the dark side. He knew that the act of redemption would occur as Vader chose to kill Emperor Palpatine, a Sith Lord (and master of the dark side). In fact Lucas wrote the entire tale in a book, called The Journal of the Whills, from which the six movies were taken.

Lucas himself has embraced something like this account: "The Star Wars series started out as a movie that ended up being so big that I took each act and cut it into its own movie. (...) The original concept really related to a father and a son, and twins - a son and a daughter. It was that relationship that was the core of the story." 6 Since 1979, Lucas has contended that he took the first draft of Star Wars, cut it in half, chose the second half, and used that for the original trilogy (p. 115).

But this account is wildly inaccurate. As Chris Taylor shows in his dazzling, fun, and fact-filled book, the Star Wars series was hardly planned in advance; it involved a great deal of rethinking, improvisation, and surprise (even to Lucas). To be sure, Taylor is focused on many subjects aside from the composition of the narrative, including the entire Star Wars phenomenon, as reflected in its international explosion over time and the actions and obsessions of its countless fans. (To those who are interested in network externalities, coordination problems, solidarity

${ }^{5}<\underline{\text { http://www.scientificamerican.com/article/patternicity-finding-meaningful- }}$ patterns/>.

${ }^{6}$ Michael KAMinSKI, THE Secret History OF Star WARS: THE ART OF StORYTELling AND THE MAKING OF A MODERN EPIC, 3 (2008). 
goods, ${ }^{7}$ informational cascades, and reputational cascades, ${ }^{8}$ there is a treasure trove of material here..$\left.^{9}\right)$ But as we shall see, the composition of the Star Wars series, and its multiple twists and turns, tell us a great deal about the nature of the production of narratives in general, including those that have many authors, such as constitutional law.

My major theme shall be the immense role of serendipity, accident, and happenstance in the creative imagination, certainly in singleauthored works, and even more in multi-authored ones extending over time. Serendipity imposes serious demands on the search for coherence in both literature and law (and history and life as well). That search leads some people (like Lucas) to become "originalists" of one or another kind, pointing to some sort of Journal of the Whills and misdescribing the nature of their own creativity and authorship. The misdescription appears to respond to a serious human need, even a craving (in both literature and law), but it is a significant obstacle to understanding and critical reflection. Human beings like patterns, but sometimes they do not find but instead create them.

\section{II. “I AM YOUR FATHER”}

To readers who are not interested in Star Wars, a cautionary note: Some of the following is going to seem (let's say) a bit obscure; you might want to do some serious skimming. We'll get to the larger themes before long.

\section{Origins}

When Lucas began, he was not, in fact, writing about "a father and a son, and twins." In Taylor's words, "the course of creativity rarely runs smooth" (p. 102). A significant part of Lucas's start involved an apparently random list of a large number of names, most of which never made it into the movies: Emperor Ford Xerxes the Third; Xenos; Han Solo

${ }^{7}$ Cass R. Sunstein \& Edna Ullmann-Margalit, Solidarity Goods, 9 JOURNAL OF POLITICAL PHILOSOPHY 2 (2001).

8 Timur Kuran, Ethnic Norms and Their Transformation through Reputational Cascades, 27 THE JOURNAL OF LEGAL STUDIES 2 (1998).

9 The discussion in DunCAN WATTS, EVERYTHING Is OBVIOUS: ONCE YOU KNOW THE ANSWER, 76-81 (2011), is highly relevant. 
("leader of the Hubble people"); Thorpe; Roland; Lars; Kane; Luke Skywalker ("Prince of Bebers"). Lucas apparently had just one scene clear in his mind, a kind of dogfight in outer space, in which ships "would hurtle and tumble around after each other, like World War II fighters, like wild birds" (p. 103).

When he finally started the story that became A New Hope, he began with a scene that featured now-familiar names for unfamiliar and nowjarring characters, including an eighteen-year-old named Annikin Starkiller (note to the cogniscienti: that is the original spelling), who lived with his father, Kane, and his brother Deak. A tall Sith knight kills Deak, and Kane asks an old friend, General Luke Skywalker, to train Annikin as a Jedi. There is a brief mention of the Force early in the story. King Kayos, leader of the planet Aquilae, sends his senators off with the words, "May the Force of Others be with you all." The idea is otherwise unexplained. Later drafts distinguished between the "Ashla Force," which was the light side, and the "Bogan force," which was the dark, and emphasized the role of something called the "Kiber Crystal" in amplifying the power of the Force of Others. All this was of course abandoned as Lucas rewrote the story (and as Luke, not coincidentally Lucas' namesake, ran away with the narrative).

Even at relatively late stages in the drafting, Lucas did not think that Darth Vader was Luke's father. Nor did he seek to preserve ambiguity on that count. Actually he thought that Darth Vader was not Luke's father. (It is an originalist myth that "Darth Vader" is a play on "Dark Father."10) When he wrote A New Hope and The Empire Strikes Back, he did not think that Luke and Leia were twins. On the contrary - and as the unmistakable sexual tension between the two suggests - he thought that they were not siblings. When Lucas began The Empire Strikes Back, he suggested that Luke had a "twin sister on the other side of the universe - placed there for safety; she too is being trained as a Jedi" (p. 232). So much for the idea that Luke and Leia were to be twins from the beginning.

With respect to Darth Vader, Taylor shows that Lucas had no act of redemption in mind. Even in the early drafts of Return of the Jedi, Vader was not redeemed, but was instead rendered irrelevant, as Grand Moff Jerrjerrod became the Emperor's new favorite (p. 267). Nor did Lucas have any sense, at the initial stages, that Palpatine would turn out to be a Sith Lord. And by the way, the mysterious and much-discussed Journal of the Whills did not exist, except as a very brief early fragment (as elaborated in particular detail by Michael Kaminski in his comprehensive

10 The best discussion is Michael KAMINSKI, THE SECRET HistORY OF STAR WARS: THE ART OF STORYTELLING AND THE MAKING OF A MODERN EPIC, 469-486 (2008).

2 JOURNAL OF INSTITUTIONAL STUDIES 2 (2016) 
2008 book, The Secret History of Star Wars $\left.{ }^{11}\right)$.

\section{Serendipity and Coherence}

Of these various points, the most important by far, and the one that can be taken to stand for the whole, is that Lucas decided only at a relatively late stage that Darth Vader is Luke's father. The "I am your father" moment - which will play a large role in this review, and which has analogues in many fields, including law -- is one in which Lucas took Star Wars on a fresh narrative path, one that fit well (enough) with what had gone before, but that cast an entirely new light on it, and that was essentially unanticipated by Lucas himself. Lucas has insisted that he "had Vader in mind as Luke's father all along" (p. 237), but far more revealingly, he said in 1993, "When you're creating something like that, the characters take over, and they begin to tell the story apart from what you're doing. ... Then you have to figure out how to put the puzzle back together so it makes sense" (p. 237).

Taylor explains that while writing the climactic scene of The Emperor Strikes Back, Lucas decided that Vader should say to Luke, "We will rule the galaxy as father and son." Those words apparently jarred his imagination, producing what must have been an "aha," a shiver, a tingle in the spine, suddenly explaining "at a strike why everyone from Uncle Owen to Obi-Wan to Yoda has been so concerned about Luke's development, and whether he would grow up to be like his father."

In the Star Wars series, as in many works of literature (and law), "I am your father" moments and their accompanying shivers are defining; they involve pivotal transitions and reversals of course that nonetheless maintain continuity with the previous story, which now becomes different and deeper. (In constitutional law, many law professors argue for such moments, for example by recognizing new limits on the power of the federal government or new rights of various sorts ${ }^{12}$; I will return to this point.) They also created a significant challenge for Lucas, because they meant that viewers had to reassess past scenes, sometimes in fundamental ways. (Lucas did have a lot of help, including friendly critics such as Steven Spielberg and close colleagues such as Lawrence Kasdan, co-writer of The Empire Strikes Back and Return of the Jedi, but to a

11 See Michael KAMINSKI, THE SeCREt History of StAR WARS: THE ART OF STORYTELLING AND THE MAKING OF A MODERN EPIC, 447-463 (2008).

12 See, e.g., RANDY BARNETT, RESTORING THE LOST CONSTITUTION: THE PRESUMPTION OF LIBERTY (2013).

2 JOURNAL OF INSTITUTIONAL STUDIES 2 (2016) 
remarkable extent, the central plots are Lucas' own.) If the reassessment produced utter incredulity in the audience - not an "OMG" but a "WTF?" - any "I am your father" moment would not work.

Suppose, for example, that Vader said, "I am your son," or "I am your cat," or "I am Captain Kirk," or even, "I am R2D2." If so, the whole thing would have been a mess. What was needed was a kind of audience gasp that contained at once genuine astonishment, even a moment of disbelief, and then a kind of awed, "it all makes sense now." The best mysteries work just that way. Gone Girl is a recent example13; A.S. Byatt's magnificent Possession ${ }^{14}$ has a number of such moments, and on this count, Shakespeare was of course the master of Jedi masters. As we shall see, something similar can be said for the greatest judicial opinions in constitutional law. (Brown v. Bd. of Educ. is an iconic "I am your father" moment.) If viewers can reassess past scenes in a way that makes the "I am your father" moment seem intelligible and in retrospect even inevitable, the indispensable sense of a coherent narrative is preserved. With the best such moments, people cannot, at some point in the future, imagine that things might possibly have been otherwise.

Even as it was, the "I am your father" moment in The Empire Strikes Back produced an acute dilemma: In A New Hope, Obi-Wan Kenobi had told Luke that Darth Vader "killed your father." Was he lying? If he was, then Obi-Wan had some serious explaining to do. Why would the sainted Obi-Wan lie to young Luke? Lucas produced an ingenious solution to this problem. In Return of the Jedi, he had Obi-Wan explain: "Your father... was seduced by the Dark Side of the Force. He ceased to be Anakin Skywalker and 'became' Darth Vader. When that happened, the good man who was your father was destroyed. So what I told you was true... from a certain point of view." In certain circles, this explanation is infamous ("from a certain point of view" can be taken as a confession of untruthfulness), but it makes sufficient sense to preserve the coherence of the narrative.

What about the fact that Luke and Leia turned out to be twins? In a way, that particular "I am your father" moment turned out to be even more challenging. Mark Hamill himself said, "This just seemed a really lame attempt to top the Vader thing" (p. 263). That "lame attempt" was made in large part because in The Empire Strikes Back, Lucas had Yoda say, in response to Obi-Wan's suggestion that Luke was their "last hope," that "there is another." As Taylor explains, Lucas wrote this mysterious and intriguing suggestion in part to "enhance the audience's perception of Luke's jeopardy; the story doesn't need him?" (p. 263). The suggestion

13 See Gillian FlynN, GONE GIRL (2013).

${ }^{14}$ ANTONIA SusAn ByatT, POSSESSION: A ROMANCE (1990). 
also opened up the possibility of Episodes VII, VIII, and IX, focusing on the twin sister. But when it came time to write Return of the Jedi, Lucas and his actors had little interest in making more movies. How then to solve the mystery - and also to resolve the romantic triangle that involved Han Solo, Luke, and Leia?

Lucas' solution was to make clear that Leia was the other and that two members of the triangle were twins. The sexual charge between the siblings in A New Hope and The Empire Strikes Back did create a problem. As noted, Lucas' solution was to ignore it. (Were those scenes dicta?) And to hammer home (a bit heavy-handedly) the plausibility of their sibling status, he has Leia say, in response to the news, "I know; I've always known." Apparently Lucas hoped that if Leia herself always knew, then the audience might think that their blood relationship was credible, even planned, and not a bizarre, coherence-destroying shift from what had gone before. (Lawyers will be able to think here of their preferred legal analogies, and some communications offices, in some White Houses, like to start communications with the words, "From Day One.")

And then there is, of course, Hans Solo's immortal line, "It's the ship that did the Kessel Run in less than twelve parsecs." With its irresistible specificity, and its combination of immediate familiarity ("less than twelve parsecs" sounds real) and foreignness (what's "the Kessel Run?"), the line, delivered with suitable self-satisfaction by Harrison Ford, captures much of what makes the series work. (The line actually has absolutely nothing to do with this review, but I can't resist mentioning it.)

The original trilogy, and in fact the entire set of six, could easily be called, "The Redemption of Annakin Skywalker," even though Lucas originally conceived of Darth Vader as a relatively minor character (just nine minutes of screen time in A New Hope!), and even though the redemption theme was itself a very late thought, almost an afterthought. In this respect, the series does not, on reflection, cohere, though its lack of coherence makes it far more interesting. The second trilogy, detailing Annakin's turn to the Dark Side, is ostensibly about one thing above all: the perils of attachment. Influenced by Buddhism, Lucas self-consciously portrayed a person turning to evil because he could not "let go" - of his mother and of his beloved. Fear of loss of attachment is Annakin's downfall. In Yoda's ominous words, ominously delivered: "Fear is the path to the dark side. Fear leads to anger. Anger leads to hate. Hate leads to suffering."

But in Return of the Jedi, Vader is redeemed not by distance but by attachment. He cannot bear to see his son die, and that is why he kills the Emperor. He is redeemed by love, not distance -- and so he is, when 
redeemed, continuous with his earlier self, showing the very characteristics that lead him to the dark side. Lucas' unconscious mind, ultimately pressing that theme, turned out to be more complicated than his apparent intentions. (On this count, the Force was unquestionably with him.)

Taylor's subtitle is "the past, present, and future of a multibillion dollar franchise," and his book goes back and forth from present-day enthusiasts (including members of a Navajo tribe, seeing the movie in its native language) to Lucas' early influences (including Buck Rogers and Flash Gordon). Taylor has numerous tales to tell, loosely organized under the Star Wars rubric. If you are interested in how the story actually developed, you can find the essential narrative here (though Kaminski's secret history is far more elaborate ${ }^{15}$ ).

Now to my main theme: That narrative offers broad lessons not only for movies, but also for creativity of many different kinds, and in areas that include novels, poems, histories, music, and law. Those lessons involve, above all, the perils of serendipity neglect, the impossibility of planning (in literature or law), the eruptive nature of the creative imagination (in literature and law), and the (challenging but ultimately blessed) difficulty of achieving coherence.

\section{THE “I AM YOUR FATHER” CONSTITUTION}

\section{An Arresting Metaphor}

In his influential account of legal reasoning, ${ }^{16}$ Ronald Dworkin provided the arresting metaphor of a chain novel. Assume (my barebones example, not Dworkin's) that ten people are charged with producing a novel, with each person asked to produce a specified chapter. Jones writes chapter one - say, about a woman, a business traveller, who turns out to seated next to a man on a plane, also a business traveller, on a flight from New York to San Francisco. Smith writes chapter two, and details the conversation between the two. As Smith develops the plot, neither is married, and romantic sparks start to fly between them. Now it is Wilson's turn. What will her third chapter look like?

${ }^{15}$ See Michael KAMINSKI, THE SeCret History OF StAR WARS: THE ART OF

STORYTELLING AND THE MAKING OF A MODERN EPIC (2008).

${ }^{16}$ RONALD DWORKIN, LAW'S EMPIRE (1986). 
Dworkin urges that if she is to be faithful to her task, she will want to make the emerging novel the best that it can be. To do that, she will have to fit what has gone before. If the flight suddenly diverts toward Tatooine (Luke's home planet), or if the woman turns out to be a Sith, the story will lose coherence (unless Wilson is very clever). Simple and abstract though their chapters are, Jones and Smith have imposed real constraints on Wilson. But within the constraints of fit, Wilson will have many options, some evidently better than others. If the two characters lose interest in one another and start reading the newspaper, the plot will not go anywhere. If the woman in the story turns out to be a fugitive from justice, because she worked for the CIA and has recently been accused of leaking classified materials, the story might turn out to be pretty interesting, or perhaps pretty silly.

Dworkin claims that the chain novel metaphor tells us a great deal about the nature of interpretation in general and legal interpretation in particular. Let us bracket some objections ${ }^{17}$ and notice that for writers of narratives, and perhaps writers in general, the metaphor captures the intrapersonal case, not only the interpersonal one. Certainly this has been true for George Lucas. Many authors (of both fiction and nonfiction) start with a vision or a kernel or an idea - a first paragraph, a first page, a scene without any clear sense of ultimate direction or of how to get there. (This review, by the way, is an example.) The vision or the kernel is what starts everything off. They have no Journal of the Whills, setting out everything in advance. As the authors build their narrative, there is constant attention to fit and justification. If there is an "I am your father" moment - and many creative writers hope that there will be -- it tends to erupt from the unconscious, and it must cohere with what has gone before.

\section{2. “I Don't Like That and I Don't Believe That"}

Here is an example of the construction of narrative, in real time, from the actual writing of The Return of the Jedi, involving Lucas and his great collaborator Lawrence Kasden ${ }^{18}$ :

\footnotetext{
${ }^{17}$ It is important, for example, to specify the nature of fit, and to understand the relationship between fit and justification. An originalist might contend that all that matters is with the original understanding of the Constitution and that judicial precedents are not important.

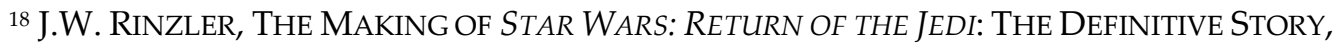
64 (2013).
} 
Kasdan: I think you should kill Luke and have Leia take over.

Lucas: You don't want to kill Luke.

Kasdan: Okay, then kill Yoda.

Lucas: I don't want to kill Yoda. You don't have to kill people. You're a product of the 1980s. You don't go around killing people. It's not nice.

Kasdan: No, I'm not. I'm trying to give the story some kind of an edge to it.

(...)

Lucas: By killing somebody, I think you alienate the audience.

Kasdan: I'm saying that the movie has more emotional weight if someone you love is lost along the way; the journey has more impact.

Lucas: I don't like that and I don't believe that.

Kasdan: Well, that's all right.

Lucas: I have always hated that in movies, when you go along and one of the main characters gets killed. This is a fairytale. You want everybody to live happily ever after and nothing bad happens to anybody.... The whole point of the film, the whole emotion that I am trying to get at the end of this film, is for you to be real uplifted, emotionally and spiritually, and feel absolutely good about life. That is the greatest thing that we could possibly ever do.

In my view, Lucas wins the argument by knockout, in terms of both fit and justification. (Precious words: "I don't like that and I don't believe that.") But Yoda does end up dying. (Kind of.)

For law, the chain novel analogy, including the Star Wars example, is not perfect or precise. A movie or a novel is bounded in the sense that it has an ending. (We may hope that this is not true for the Star War series, but still.) Law is not similarly bounded in time. One implication is that in law, new and unanticipated circumstances and problems will inevitably arise, making it especially difficult or perhaps even impossible to ensure coherence. (Consider the rise of the telephone and the Internet, the increase in national markets, the changing role of women, new norms with respect to sexual orientation.) With the unending serial that is constitutional law, some kind of plot twist might turn out to be inevitable (and not merely to avoid monotony).

The problem is complicated by the fact that constitutional law has numerous authors, not only at a single moment in time, but also over long periods, and often with fundamentally different ideas (certainly about justification). A small group of people, working in the same week or month or year, might be able to create a coherent narrative. This is much harder for dozens of diverse people, with different orientations and commitments, composing a tale over decades. Appointees in the second decade of the twenty-first century might not be so excited about the 
chapters written by appointees in the second decade of the twentieth century. Appointees of a Democratic president might not want the narrative to unfold in the way sought by appointees of a Republican president. In those circumstances, we will inevitably see departures and deviations, and what seem, to some, to be extraordinary or shiverproducing "I am your father" moments will seem, to others, to be moments of betrayal or absurdity or cringe-production ("I am your cat"). Paul v. Davis, a 1976 decision that cabined the use of the due process clause, is an unmistakable example. ${ }^{19}$

It is also important that Supreme Court justices have incomplete control over their own jurisdiction. To be sure, they can deny certiorari, but if the lower courts are divided, or if the issue has great national importance, it will be hard for the Court to refuse to hear the case. Suppose that in our previous example, a chain novelist were suddenly required to write a chapter about how the woman on the plane first became interested in the CIA, or that George Lucas were suddenly required, at an inopportune time, to make a movie about Leia's childhood. If so, it would be much harder both to ensure coherence and to preserve the necessary space for the proper "I am your father" moments.

There are also differences between narrative conventions, which constrain novelists and screenwriters, and legal and political conventions, which constrain courts. A novelist could not easily spend several pages on the meaning of section 553 of the Administrative Procedure Act (unless she is exceptionally skilled), ${ }^{20}$ and a judge could not decide that for a few pages, his major goal is to make things really fun (or tragic, or silly, or sexy). While the conventions overlap (a gay Star Wars character in 1977 would have been a bold move, tracking constitutional law), they have major differences along multiple dimensions. But it remains true that the chain novel metaphor illuminates a great deal about both constraint and creativity in law.

\section{SERENDIPITY AND THE JOURNAL OF THE WHILLS}

Unfortunately, Dworkin has little to say about the role of serendipity and improvisation in legal reasoning; this is a real gap. The narrative arc of constitutional law is full of surprises and turns and reversals. After the

19 Paul v. Davis, 424 U.S. 693 (1976).

${ }^{20}$ Administrative Procedure Act, 5 U.S. Code $\S 553$ (Rule Making).

2 JOURNAL OF INSTITUTIONAL STUDIES 2 (2016) 
fact, we often take that arc as inevitable and even planned, but it really isn't so. Recall that human beings like to see designs and patterns whether or not they exist; constitutional law is a case in point.

Consider the issue of freedom of speech. For many people, including many lawyers, contemporary First Amendment doctrine is understood as if it emerged from some kind of Journal of the Whills - as if it has been spooled out of something (such as the original understanding of the text, or the basic commitments of James Madison). There are many domains in which that understanding can be shown to be false; perhaps the most obvious is commercial advertising.

Until 1976, the Supreme Court had never ruled that the First Amendment protects such advertising. In its own "I am your father" moment, the Court decided that indeed it did, in an opinion that claimed continuity with a tradition that it was fundamentally revising: "We begin with several propositions that already are settled or beyond serious dispute. (...) It is precisely this kind of choice, between the dangers of suppressing information, and the dangers of its misuse if it is freely available, that the First Amendment makes for us." ${ }^{21}$ In so saying, the Court cast a new light on, and required a fresh understanding of, what had gone before. The key words, and the not really true (meaning, false) ones, are that the choice is one "that the First Amendment makes for us." (It does no such thing.)

With the comparatively recent protection of commercial speech in view, we might venture another understanding of our free speech tradition: Political speech has long been at the "core" of that tradition, but very late in the game (1976!), the Court wrongly added commercial advertising, in a way that compromised and undermined the tradition. The protection of such advertising was a false move, one that fails the constraints of fit, and also that fails to justify what had come before. (Perhaps protection of commercial advertising is constitutional law's The Phantom Menace.) But matters are actually far more complicated than that, and the role of creativity and reversals is much larger. For the overwhelming majority of the Constitution's life, federal and state governments were permitted to punish speech that they deemed to be dangerous, even if that speech did not create anything like a clear and present danger. As late as 1960, and possibly somewhat latter, dissenters were at serious risk if the government really wanted to punish them. ${ }^{22}$

${ }^{21}$ Virginia State Board of Pharmacy v. Virginia Citizens Consumers Council, 425 U.S. 748 (1976).

22 See, e.g., Dennis v. United States, 341 U.S. 494 (1951), which remained good law until Brandenburg v. Ohio, 395 U.S. 444 (1969). 
The robust protection now given to political speech is a creation of a brief (and late, and shining) moment in time, punctuated by several "I am your father" decisions, most prominently in 1964 (New York Times $v$. Sullivan ${ }^{23}$ ) and 1969 (Brandenburg v. Ohio ${ }^{24}$ ). In using the First Amendment as a barrier to much of state libel law in Sullivan, the Court asserted a truth that requiring a rethinking of all that had come before: "the pall of fear and timidity imposed upon those who would give voice to public criticism is an atmosphere in which the First Amendment criticisms cannot survive." (Is that a truth? Maybe. But in a parallel world, of the sort that Star Wars did not explore - Star Trek does $^{25}$ - the Court did not think so.)

What can be said about the First Amendment can be said about countless domains of constitutional law. The current protection against racial discrimination is a product of the 1950s. ${ }^{26}$ (Sure, the Equal Protection Clause followed the Civil War, but it is a wild stretch, a form of Leia-like "I've always known," to say that current equal protection doctrine can be read off the Clause.) Religious liberty, as we live it, is a product of the 1960s..$^{27}$ The ban on sex discrimination comes from the 1970 s. ${ }^{28}$ Sharp constraints on affirmative action are a product of the 1990s and 2000s. ${ }^{29}$ The constitutional protection afforded to individual gun ownership did not really come until the twenty-first century. ${ }^{30}$

In each of these cases, lawyers and judges work hard to point to a Journal of the Whills, but it just isn't there. Nothing here was inevitable, and without contingent social movements and forces and judgments (to the effect of "that is the greatest thing that we could possibly ever do"), radically different constitutional settlements would have emerged. If they had, they would have seemed no more surprising, and no less foreordained, than what we now observe.

Consider originalism in this light. ${ }^{31}$ We have seen that when he wrote A New Hope, Lucas had no idea about major plot developments in The

${ }^{23}$ New York Times Co. v. Sullivan, 376 U.S. 254 (1964).

${ }^{24}$ Brandenburg v. Ohio, 395 U.S. 444 (1969).

$25<$ http://en.memory-alpha.org/wiki/Mirror universe>.

${ }^{26}$ See Brown v. Board of Education, 347 U.S. 483 (1954).

${ }^{27}$ See Engel v. Vitale, 370 U.S. 421 (1962).

${ }^{28}$ See Califano v. Goldfarb, 430 U.S. 199 (1977).

${ }^{29}$ See Grutter v. Bollinger, 539 U.S. 306 (2003).

${ }^{30}$ See District of Columbia v. Heller, 554 U.S. 570 (2008).

31 There are many different varieties. I am speaking of the kind defended in ANTONIN SCALIA, A MATTER OF INTERPRETATION: FEDERAL COURTS AND THE LAW (1998), rather than in JACK BALKIN, LIVING ORIGINALISM (2012). 
Empire Strikes Back and Return of the Jedi. It would have been preposterous for him, and for his coauthors and (as of 2015) successors, to write further installments with reference to this question: What was Lucas' original understanding? With respect to central issues in the series, there is no such understanding to consult, and with respect to others, it points in the wrong direction (as Lucas himself concluded). For constitutional law, the problem is immensely compounded because of the temporal lag between that understanding and current problems, and because of the rise of unanticipated circumstances of multiple kinds. ${ }^{32}$

In any particular period, constitutional law conveys an aura of inevitability, as if the prevailing narrative were planned or foreordained, or a product of some kind of Journal of the Whills. Assuming the role of Jedi, many originalists, evidently concerned to preserve the constitutional status quo, have worked exceedingly hard to demonstrate that wide swaths of current doctrine actually follow from the original understanding, even if that doctrine was established in the 1950s, the 1980s, the 2000s, or last year. ${ }^{33}$ Also self-portrayed Jedi, many nonoriginalists make similar claims, contending that they are speaking for the animating purposes of the provisions that they are interpreting, ${ }^{34}$ or spelling out the inner logic of those provisions.

Don't believe them. Whether Jedi or Sith, many authors of constitutional law are a lot like the author of Star Wars, disguising the essential nature of their own creative processes.

\section{REFERENCES}

ANTONIA Susan Byatt, Possession: A Romance (1990).

ANTONIN SCALIA, A MATTER OF INTERPRETATION: FEDERAL COURTS AND THE LAW (1998).

32 This is not a claim in favor of abandoning the text - any more than it is a claim than that Lucas should have abandoned the text of A New Hope. The question involves the role of the original understanding of the text.

${ }^{33}$ See, e.g., Michael McConnell, Originalism and the Desegregation Decisions, 81 VIRGINIA

LAW REVIEW 4 (1995).

34 STEPHEN BREYER, ACTIVE LiBERTY: INTERPRETING OUR DEMOCRATIC CONSTITUTION

(2005), can be read in this way, though I think his argument is more subtle. 
Cass R. Sunstein \& Edna Ullmann-Margalit, Solidarity Goods, 9 JoURNAL OF POLITICAL PHILOSOPHY 2 (2001).

CHRIS TAYLOR, HOW STAR WARS CONQUERED THE UNIVERSE: THE PAST, PRESENT, AND FutURE OF A MULTiBILLION FRANCHISE (2014).

DUNCAN WATtS, EvERYTHING Is OBviOUs: OnCE YOU KNOW THE ANSWER (2011).

GILLIAN FLYNN, GONE GIRL (2013).

J.W. RINZLER, THE MAKING OF STAR WARS: RETURN OF THE JEDI: THE DEFINITIVE STORY (2013).

JACK BALKIN, LiVING ORIGINALISM (2012).

Michael Drosnin, The Bible Code (1998).

Michael KAMINSKI, THE SECRET History OF STAR WARS: THE ART OF STORYTELLING AND THE MAKING OF A MODERN EPIC (2008).

Michael McConnell, Originalism and the Desegregation Decisions, 81 VIRGINIA LAW REVIEW 4 (1995).

RANDY BARNETT, RESTORING THE LOST CONSTITUTION: THE PRESUMPTION OF LIBERTY (2013).

RONALD DWORKIN, LAW'S EMPIRE (1986).

STEPHEN BREYER, ACTIVE LIBERTY: INTERPRETING OUR DEMOCRATIC CONSTITUTION (2005). 
Timur Kuran, Ethnic Norms and Their Transformation through Reputational Cascades, 27 THE Journal OF Legal StUdies 2 (1998).

How Star Wars Illuminates Constitutional Law Como o Filme Guerra nas Estrelas Ilumina o Direito Constitucional Submitted: 2016-11-28

Accepted: 2017-01-30

2 JOURNAL OF INSTITUTIONAL STUDIES 2 (2016) 